\title{
ANALISA WAKTU TUNGGU PELAYANAN RAWAT JALAN DI RS UNIVERSITAS BRAWIJAYA
}

\author{
Wahyu Purnomo \\ Program Studi Magister Manajemen Rumah Sakit Fakultas Kedokteran \\ Universitas Brawijaya, Malang \\ adik.nunu@gmail.com \\ Tita Hariyanti \\ Program Studi Magister Manajemen Rumah Sakit Fakultas Kedokteran \\ Universitas Brawijaya, Malang \\ Wening Prastowo \\ Rumah Sakit Universitas Brawijaya Malang
}

Masuk : 12-01-2020, revisi : 20-02-2021 diterima untuk diterbitkan : 22-02-2021

\begin{abstract}
Waiting time for patient services is one indicator of patient satisfaction and quality of service in a hospital. The length of time a patient is waiting is one of the important things in determining the quality of health services. Based on the results of preliminary studies that have been carried out at Universitas Brawijaya Hospital in Malang, the implementation of outpatient services is still not running optimally. During the study the waiting time for outpatient services was more than 143 minutes (minimum service standard $<60$ minutes). The purpose of this study was to determine the factors that influence the length of waiting time for outpatient services and solution solutions. Researchers used qualitative methods, data collection was done by unstructured interviews, Focus Group Discussions, and observations with time and motion study. The number of participants was 30 people. The final results of the study, are the factors that influence the waiting time of outpatient visitors are the queuing number collection system and the medical record file ordering system. Solutions for long waiting times for patients in outpatient services that affect patient satisfaction by changing the Medical Record file order system and changing the queue number group.
\end{abstract}

Keywords: Outpatient, Waiting Time, Outpatients, Qualitative, Focus Group Discussion

Abstrak: Waktu tunggu pelayanan pasien merupakan salah satu indikator kepuasaan pasien dan mutu pelayanan di rumah sakit. Lamanya waktu tunggu pasien merupakan salah satu hal penting dalam menentukan kualitas pelayanan kesehatan. Berdasarkan hasil studi pendahuluan yang telah dilakukan di RS Universitas Brawijaya di kota Malang pelaksanaan pelayanan pasien di rawat jalan masih belum berjalan optimal. Saat penelitian waktu tunggu pelayanan rawat jalan lebih dari 143 menit (setandar pelayanan minimal $<60$ menit). Tujuan penelitian untuk mengetahui faktor yang mempengaruhi lama waktu tunggu pelayanan rawat jalan dan solusi pemecahan. Peneliti menggunakan metode kualitatif, pengumpulan data dilakukan dengan wawancara tidak terstruktur, Focus Group Discussion, dan observasi dengan time and motion study. Jumlah participan 30 orang. Hasil akhir penelitian, adalah faktor yang mempengaruhi lama waktu tunggu pengunjung rawat jalan adalah sistem pengambilan nomor antrian dan sistem pemesanan berkas rekam medis. Solusi untuk lama waktu tunggu pasien di pelayanan rawat jalan yang mempengaruhi kepuasan pasien dengan merubah sistem pemesanan berkas Rekam Medis dan merubah kelompok nomor antrian.

Kata Kunci: Rawat Jalan, Waktu Tunggu, Pasien Rawat Jalan, Kualitatif, Focus Group Discussion 


\section{PENDAHULUAN}

Salah satu standar pelayanan minimal adalah waktu tunggu pelayanan di rawat jalan. Pada standar pelayanan minimal (SPM) disebutkan bahwa waktu tunggu pelayanan adalah kurang dari 60 menit. Waktu tunggu yang lama merupakan salah satu permasalahan yang banyak ditemukan di instalasi rawat jalan rumah sakit. Waktu tunggu adalah waktu tunggu yang dipergunakan oleh pasien untuk mendapatkan pelayanan rawat jalan dan rawat inap dari tempat pendaftaran sampai masuk ke ruang pemeriksaan dokter (Depkes RI, 2007). Data laporan tahunan rumah sakit tentang angka keterlambatan dokter terhadap jam praktek sebesar 8,7\% dari target 5\% SPM rumah sakit. Waktu tunggu adalah salah satu komponen yang dirasakan langsung oleh pelanggan yang tidak hanya mencerminkan waktu tunggu sebenarnya tetapi juga lebih dipengaruhi persepsi pasien (David et al., 2014).

\section{TELAAH KEPUSTAKAAN}

Kepuasan pasien merupakan cerminan kualitas pelayanan kesehatan yang mereka terima (Azwar, 1994). Pasien akan merasa puas jika apa yang diharapkan bisa diberikan oleh pemberi layanan. Tingkat kepuasan setiap pasien akan berbeda-beda karena dipengaruhi banyak faktor, diantaranya faktor budaya, pendidikan, ekonomi dan sosial. Mutu pelayanan kesehatan merujuk pada tingkat kesempurnaan pelayanan kesehatan dalam menimbulkan rasa puas pada diri setiap pasien. Semakin tinggi tingkat kepuasan tersebut, makin baik pula mutu pelayanan kesehatan. Kualitas pelayanan yang relatif baik belum tentu bisa memuaskan pasien. Pada umumnya pasien tidak dapat menilai kompetensi teknis, sehingga mereka menilai mutu layanan dari karakteristik nonteknis atau hubungan interpersonal dan kenyamanan pelayanan (Blank, 1982). Menurut hasil penelitian ditemukan adanya perbedaan dimensi, yaitu:

1. Bagi pemakai jasa pelayanan kesehatan, mutu pelayanan kesehatan lebih terkait pada dimensi ketanggapan petugas memenuhi kebutuhan pasien, kelancaran komunikasi petugas dengan pasien, keprihatinan serta keramahtamahan petugas dalam melayani pasien dan atau kesembuhan penyakit yang sedang diderita pasien.

2. Bagi penyelenggara pelayanan kesehatan, mutu pelayanan kesehatan lebih terkait pada dimensi kesesuaian pelayanan yang diselenggarakan dengan perkembangan ilmu dan teknologi mutakhir dan atau otonomi profesi dalam menyelenggarakan pelayanan kesehatan sesuai dengan kebutuhan pasien.

3. Bagi penyandang dana pelayanan kesehatan, mutu pelayanan kesehatan lebih terkait pada dimensi efisiensi pemakaian sumber dana, kewajaran pembiayaan kesehatan dan atau kemampuan pelayanan kesehatan mengurangi kerugian penyandang dana pelayanan kesehatan.

Perbedaan dimensi itulah yang sering menimbulkan kekecewaan pasien, meskipun petugas sudah menerapkan standar operasional prosedur dengan baik. Oleh karena itu aspek kepuasan pelanggan perlu mendapatkan perhatian serius, karena meski bersifat subyektif tetapi menentukan preferensi selanjutnya dalam memilih sarana pelayanan kesehatan (Supartiningsih, 2017). Pelayanan yang baik ataupun buruk tentunya akan menghasilkan kesan tersendiri sebagai ungkapan kepuasan atau ketidakpuasannya akan pelayanaan yang diterima oleh konsumen (Lestari, 2019)

Tujuan dari penelitian ini adalah meningkatkan kepuasan pasien dengan memperpendek waktu tunggu pelayanan di rawat jalan. Waktu tunggu yang dimaksud dalam penelitian ini adalah proses sejak mengambil nomor antrian sampai bertemu dengan dokter yang dimaksud oleh pengunjung.

\section{METODOLOGI PENELITIAN}

Penelitian dilakukan pada bulan Agustus - Oktober 2019. Metode yang dilakukan pada penelitian ini adalah wawancara tidak terstruktur, Focus Grup Discussion (FGD), dan observasi dengan cara time and motion study. Proses yang diteliti adalah pada pelayanan rawat 
jalan mulai dari pengambilan tiket antrian sampai bertemu dokter. Wawancara dan $F G D$ dilakukan untuk menggali akar permasalahan yang ada dan mendapatkan alternative solusi. FGD dihadiri oleh 12 pegawai rumah sakit. Observasi time and motion study dilakukan dengan mengamati dan mencatat durasi waktu pada setiap alur pelayanan rawat jalan yang melibatkan 2 petugas informasi untuk mengambil antrian, 3 petugas pendaftaran, 2 petugas rekam medis dan 5 perawat rawat jalan yang merangkap asisten dokter. Analisa penelitian data survey dianalisis menggunakan Software Microsoft Office Excel dan Software Minitab.

\section{ANALISA DAN PEMBAHASAN}

Pengumpulan data dilakukan dengan melakukan observasi di rawat jalan dengan melakukan pencatatan waktu proses pelayanan (time and motion study). Hasil waktu tunggu seperti tabel dibawah ini:

\section{Tabel 1}

Waktu tunggu pelayanan Sebelum Intervensi

\begin{tabular}{cccccc}
\hline & & \multicolumn{3}{c}{ Lama Waktu Tunggu } & \multirow{2}{*}{ Total } \\
\cline { 3 - 5 } & datang & Registrasi & Kajian awal & Ke dokter & \\
\hline 1 & $09: 10$ & $01: 18: 24$ & $00: 31: 02$ & $00: 33: 30$ & $02: 22: 56$ \\
2 & $09: 13$ & $01: 06: 22$ & $00: 30: 21$ & $00: 29: 13$ & $02: 05: 56$ \\
3 & $09: 15$ & $01: 10: 03$ & $00: 28: 13$ & $00: 35: 36$ & $02: 13: 52$ \\
4 & $09: 20$ & $01: 03: 56$ & $00: 33: 22$ & $00: 25: 17$ & $02: 02: 35$ \\
5 & $09: 22$ & $01: 09: 03$ & $00: 34: 51$ & $00: 22: 39$ & $02: 06: 33$ \\
6 & $09: 25$ & $01: 03: 42$ & $00: 24: 17$ & $00: 36: 12$ & $02: 04: 11$ \\
7 & $09: 28$ & $01: 00: 56$ & $00: 24: 45$ & $00: 22: 20$ & $01: 48: 01$ \\
8 & $09: 30$ & $00: 58: 44$ & $00: 22: 19$ & $00: 26: 28$ & $01: 47: 31$ \\
9 & $09: 33$ & $01: 02: 16$ & $00: 32: 24$ & $00: 31: 18$ & $02: 05: 58$ \\
10 & $09: 37$ & $01: 12: 22$ & $00: 29: 15$ & $00: 36: 21$ & $02: 17: 58$ \\
\hline
\end{tabular}

Sumber : Data Primer penelitian bulan Agustus - Oktober 2019

Waktu terlama sebelum intervensi adalah 2 jam 22 menit mulai dari pasien datang sampai bertemu dengan dokter. Dan waktu terpendek adalah 1 jam 48 menit. Dari table di atas terlihat ada 3 tahapan yang mengharuskan pengunjung menunggu untuk mendapatkan pelayanan rawat jalan. Pengunjung harus menunggu untuk melakukan registrasi, mendapat pelayanan kajian awal keperawatan dan menunggu untuk bertemu dokter. Berdasarkan data di atas maka dilakukan wawancara dan Focus Group Discussion (FGD) untuk menentukan akar masalah dan mencari alternative solusi yang paling mudah dan murah untuk dilakukan dan membawa dampak perbaikan. $F G D$ dihadiri oleh 12 orang yang melibatkan 2 dokter pelaksana, 3 perawat rawat jalan, 3 jajaran manajemen, 2 perekam medis dan 2 petugas pendaftaran. Hasil wawancara dan $F G D$ didapatkan 5 faktor yang mempengaruhi lamanya pelayanan di rawat jalan.

\section{Tabel 2}

Faktor yang mempengaruhi waktu tunggu pasien rawat jalan

\begin{tabular}{lll}
\hline No & \multicolumn{1}{c}{ Masalah } & \multicolumn{1}{c}{ Keterangan } \\
\hline 1. & $\begin{array}{l}\text { Pasien poli pagi dan poli sore daftar pada waktu yang } \\
\text { sama }\end{array}$ & \\
\hline 2. & $\begin{array}{l}\text { Pemesanan Berkas Rekam Medis dilakukan setelah > } \\
10 \text { pasien }\end{array}$ & Dilakukan melalui telepon \\
\hline 3. & $\begin{array}{l}\text { Petugas pelaksana kajian awal keperawatan merangkap } \\
\text { asisten dokter }\end{array}$ & $\begin{array}{l}\text { Jumlah poli yang memberikan } \\
\text { pelayanan lebih banyak }\end{array}$ \\
\hline 4. & Tidak ada manajer pelayanan di rawat jalan & Tidak ada Case Manager \\
\hline 5. & Belum melibatkan e SIMRS untuk pendaftaran online & Pendaftaran secara onsite \\
\hline
\end{tabular}

Sumber: Data Primer Penelitian Agustus - Oktober 2019

Dari tabel 2, didapatkan 5 faktor yang diduga mempuyai pengaruh terhadap lamanya waktu tunggu pasien rawat jalan. Dengan Focus Group Discussion dicari solusi terbaik untuk mengurangi waktu tunggu yang melebihi standar pelayanan minimal. Peserta $F G D$ yang berjumlah 12 orang memberikan pemecahan masalah yang bisa diterapkan seperti pada tabel 
3, di bawah ini. Dari hasil observasi dan wawancara didapatkan 5 akar permasalahan yang dominan. Salah satunya penumpukan pendaftaran poli pada shift pagi karena tidak adanya batasan jam pendaftaran/registrasi yang dilayani. Hal ini mengakibatkan pendaftaran akan banyak pada pagi hari dan proses antrian untuk mendapatkan pelayanan akan memanjang.

Dari data pada tabel 1, dapat dibuat gambaran statistic waktu tunggu pada setiap tahapan proses pelayanan di poli rawat jalan sebelum bertemu dengan dokter. Ada 3 tahapan antrian yang dilakukan oleh pasien sebelum bertemu dengan dokter.

1. Antri untuk melakukan registrasi/pendaftaran setelah mengambil nomor urutan pendaftaran yang terbagi menjadi 3 kelompok. $(\mathrm{A}=$ pasien non $\mathrm{BPJS}, \mathrm{B}=$ pasien $\mathrm{JKN}$ BPJS, $\mathrm{C}=$ pasien pemeriksaan penunjang)

2. Antri untuk dilakukan pengkajian awal keperawatan di nurse station yang akan dilakukan saat rekam medik sudah siap

3. Antri untuk bertemu dengan dokter.

\section{Tabel 3}

Descriptive Statistics: Waktu Tunggu Pelayanan Rawat Jalan (dalam menit)

\begin{tabular}{lccccc}
\hline \multicolumn{1}{c}{ Variable } & Mean & StDev & Minimum & Median & Maximum \\
\hline 1. Antri Registrasi & 66.58 & 5.95 & 58.73 & 65.15 & 78.40 \\
2. Antri Kajian Awal Perawat & 29.08 & 4.17 & 22.32 & 29.80 & 34.85 \\
3. Antri bertemu Dokter & 29.89 & 5.50 & 22.33 & 30.26 & 36.35 \\
\hline \multicolumn{1}{c}{ Total } & 125.55 & & 103.38 & 125.21 & 149.6
\end{tabular}

Dari Tabel 3. Menunjukan waktu tunggu mulai mengambil antrian sampai bertemu dokter spesialis, rata-rata adalah +125 menit ( 2 jam 5 menit). Jika proses antri bertemu dokter dihilangkan, maka rata-rata waktu tunggu untuk proses pendaftaran dan mendapat kajian awal keperawatan adalah + 95 menit ( 1 jam 35 menit). Waktu tunggu pelayanan rawat jalan ini tidak sesuai standar pelayanan minimal RS yaitu kurang dari 60 menit.(Depkes RI, 2007)

Ada beberapa faktor yang mengakibatkan proses pelayanan memanjang sebelum bertemu dokter. Pada awal pengambilan nomor antrian, pengunjung dibagi menjadi 3 macam kelompok, yaitu pengunjung dengan menggunakan jaminan kesehatan BPJS, pengunjung tanpa menggunakan jaminan, dan pengunjung yang akan melakukan pemeriksaan penunjang. Pembagian antrian menjadi 3 kelompok ini, dalam pengamatan peneliti, tidak efektif. Pembagian ini hanya membagi berdasarkan pembiayaan dan keperluan kedatangan pasien, tetapi tidak membagi pasien berdasarkan jam pelayanan. Sehingga pasien datang bersamaan, sedangkan poli pelayanan ada yang dimulai setelah shift siang.

Pada proses registrasi, petugas pendaftaran akan mendaftar semua pengunjung dan melakukan pemesanan berkas rekam medis. Akibatnya petugas rekam medis akan menyiapkan semua pesanan rekam medis (RM). Hal ini juga akan mempengaruhi lama waktu tunggu di poli rawat jalan. Petugas pendaftaran akan melakukan pemesanan berkas rekam medis jika mencapai 10 orang. Hal ini akan mempengaruhi lama waktu tunggu di rawat jalan. Waktu tunggu RM cepat, kurang dari atau sama dengan 10 menit, dan dalam waktu tunggu RM lama, lebih dari 10 menit.(1) Bila waktu tunggu pasien di Rekam Medis Rawat Jalan lama maka hal tersebut berpengaruh pada citra rumah sakit yang kemungkinan besar berpengaruh pada pasien di masa mendatang.(Simanjuntak, 2016)

Pada saat dilakukan penelitian, proses penyiapan berkas rekam medis masih dalam rentang memenuhi stadar pelayanan minimal, yaitu kurang dari 10 menit. Lama waktu penyiapan berkas rekam medis dihitung sejak petugas pendaftaran meminta berkas rekam medis sampai berkas siap di meja nurse station. 
Tabel 4

Tabel Efisiensi jika dilakukan pemesanan RM kurang dari 6 pasien

\begin{tabular}{|c|c|c|c|c|c|}
\hline & $>10$ patien & menit & $<6$ pasien & menit & Keterangan \\
\hline registrasi & $\begin{array}{l}\text { pasien urutan pertama } \\
\text { akan menunggu } 25 \\
\text { menit baru dipesankan } \\
\text { RM }\end{array}$ & 25 & $\begin{array}{l}\text { pasien urutan pertama } \\
\text { akan dipesankan } \\
\text { setelah } 12,5 \text { menit }\end{array}$ & 15 & $\begin{array}{c}\text { asumsi lama registrasi } \\
150 \mathrm{detik} / \text { pasien }\end{array}$ \\
\hline $\begin{array}{l}\text { penyiapan } \\
\text { berkas }\end{array}$ & $\begin{array}{l}\text { memerlukan waktu } \\
\qquad 5+3 \text { menit }\end{array}$ & 8 & $\begin{array}{c}\text { memerlukan waktu } 3 \\
+2 \text { menit }\end{array}$ & 5 & $\begin{array}{c}\text { Penyiapan berkas : } \\
\text { mencari RM dan } \\
\text { menyisipkan Surat } \\
\text { Eligibilitas Peserta } \\
\text { (SEP) }\end{array}$ \\
\hline $\begin{array}{l}\text { Kajian Awal } \\
\text { Keperawatan }\end{array}$ & $\begin{array}{l}\text { pasien urutan pertama } \\
\text { akan dilakukan kajian } \\
\text { awal perawat tercepat } \\
30 \text { menit kemudian }\end{array}$ & 30 & $\begin{array}{l}\text { pasien urutan pertama } \\
\text { akan dilakukan kajian } \\
\text { awal perawat tercepat } \\
15 \text { menit kemudian }\end{array}$ & 15 & $\begin{array}{c}\text { asumsi jika kajian } \\
\text { memerlukan sekitar } 5 \\
\text { menit dilakukan } 2 \\
\text { perawat }\end{array}$ \\
\hline
\end{tabular}

63

35

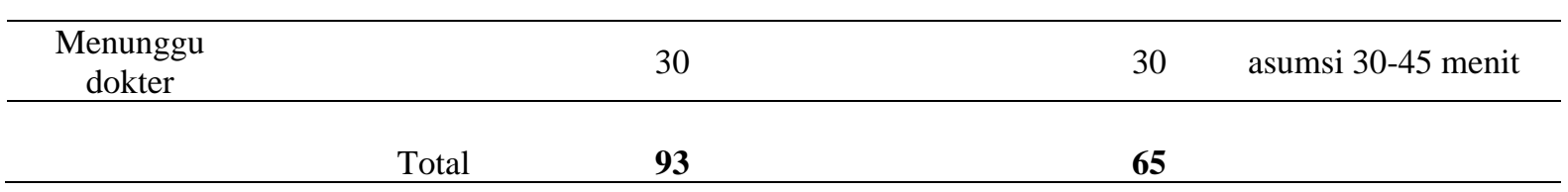

Pada Tabel 4, gambaran efisiensi waktu dengan melakukan intervensi proses pemesanan berkas rekam medis. Harapan dengan memendeknya waktu tunggu akan mengurangi keluhan dan ketidakpuasan pelanggan.(Laeliyah dan Subekti, 2017; Hidayati et al., 2014)

Lamanya waktu tunggu tidak selalu mempunyai korelasi dengan mutu pelayanan di suatu rumah sakit, beberapa pasien tidak mempermasalahkan dengan lamanya waktu tunggu. Tidak semua pelayanan dengan waktu tunggu yang pendek memberikan kepuasan kepada pelanggan.(Xie dan Or, 2017; Donahue et al., 2017)

Pemeriksaan awal oleh perawat merupakan tuntutan dari Akreditasi yang mengharuskan pasien mendapakan kajian awal keperawatan sebelum bertemu dengan dokter. Kondisi yang demikian ini mempengaruhi waktu tunggu pelayanan rawat jalan, dimana petugas yang melakukan kajian awal pada saat dilakukan penelitian juga merangkap sebagai asisten dokter. Dan jumlah petugas yang lebih sedikit daripada jumlah poli atau dokter yang berpraktek, membuat nurses station sering kosong. Kajian awal keperawatan akan tertunda akibat jumlah tenaga yang kurang.(Andria, 2015; Megawati et al., 2015)

\section{KESIMPULAN}

Waktu tunggu di pelayanan rawat jalan RSUB dipengaruhi oleh sistem pengelompok nomor antrian dan cara pemesanan berkas rekam medik. Perbaikan sistem antrian di tempat pendaftaran dan sitem pemesanan berkas rekam medis pasien memperpendek waktu tunggu pelayanan rawat jalan.

\section{REFERENSI}

Andria, F. S. (2015). Tinjauan penyediaan dokumen rekam medis di RSUD Dr. Soekidjo Kota Tasikmalaya. Jurnal Manajemen Informasi Kesehatan Indonesia.

Azwar, A. (1994). Pengantar Administrasi Kesehatan (Edisi Ketiga). Binarupa Aksara, Tangerang, Ciputat.

Blank, W. (1982). Handbook for Developing Competency-Based Training Programs. Englewood Cliffs, New Jersey: Prenice-Hall.

David, D., Hariyanti, T., \& Widayanti Lestari, E. (2014). Hubungan keterlambatan kedatangan dokter terhadap kepuasan pasien di instalasi rawat jalan. Jurnal Kedokteran Brawijaya, 28(1), 31-35. 
Depkes RI. (2007). Standar pelayanan minimal rumah sakit. Direktorat Jendral Bina Pelayanan Medika. Jakarta.

Donahue, R. et al. (2017). Patients willing to wait: Arrival time, wait time and patient satisfaction in an ambulatory urology clinic. Urology Practice, 4(1), 1-6. Available at: http://www.jurology.com/doi/10.1016/j.urpr.2016.02.003.

Hidayati, A. N., Suryawati, C., \& Sriatmi, A. (2014). Analisis hubungan karakteristik pasien dengan kepuasan pelayanan rawat jalan Semarang Eye Center (SEC) Rumah Sakit Islam Sultan Agung Semarang. Jurnal Kesehatan Masyarakat (e-Journal).

Laeliyah, N., \& Subekti, H. (2017). Waktu tunggu pelayanan rawat jalan dengan kepuasan pasien terhadap pelayanan di rawat jalan RSUD Kabupaten Indramayu. Jurnal Kesehatan Vokasional.

Lestari, B. A. (2019). Pengaruh waktu tunggu, harga dan kualitas pelayanan terhadap kepuasan konsumen pada maskapai Garuda Indonesia di Terminal 3 Bandara Soekarno Hatta. Jurnal Manajemen Bisnis dan Kewirausahaan, 2(4), 120-126. Available at: https://journal.untar.ac.id/index.php/jmbk/article/view/4856.

Megawati, M., Hakim, L., \& Irbantoro, D. (2015). Penurunan waktu tunggu pelayanan obat rawat jalan instalasi farmasi rumah sakit Baptis Batu. Jurnal Kedokteran Brawijaya.

Simanjuntak, M. (2016). Tinjauan faktor-faktor yang mempengaruhi waktu tunggu pelayanan rekam medis di pendaftaran rawat jalan di RSUD Dr. R. M. Djoelham Binjai tahun 2015. Jurnal Ilmiah Perekam dan Informasi Kesehatan Imelda.

Supartiningsih, S. (2017). Kualitas pelayanan an kepuasan pasien rumah sakit: Kasus pada pasien rawat jalan. Jurnal Medicoeticolegal dan Manajemen Rumah Sakit, 6(1), 9-15.

Xie, Z., \& Or, C. (2017). Associations between waiting times, service times, and patient satisfaction in an endocrinology outpatient department: A time study and questionnaire survey. Inquiry : A Journal of Medical Care Organization, Provision and Financing, 54, hal.46958017739527-46958017739527.

Available

at: https://www.ncbi.nlm.nih.gov/pubmed/29161947. 